\title{
RESEARCH NOTE \\ Effects of different poultry manure fertilization levels and cutting times on Moringa oleifera production
}

\section{Mouchili Mouchili', Fernand Tendonkeng ${ }^{1}$, Emile Miégoué1, David Fokom Wauffo ${ }^{1}$, Hippolyte Mekuiko Watsop ${ }^{1}$, Etienne Pamo Tedonkeng ${ }^{1}$, and Einar Vargas-Bello-Pérez ${ }^{2}$}

${ }^{1}$ Université de Dschang, Département de Zootechnie, FASA, Laboratoire de Nutrition Animale. B.P: 222 Dschang, Cameroun.

${ }^{2}$ University of Copenhagen, Faculty of Health and Medical Sciences, Department of Veterinary and Animal Sciences. Grønnegårdsvej 3, 1870 Frederiksberg C, Denmark.

\begin{abstract}
M. Mouchili, F. Tendonkeng, E. Miégoué, D. Fokom Wauffo, H. Mekuiko Watsop, P.E. Tedonkeng, and E. Vargas-Bello-Pérez. 2019. Effects of different poultry manure fertilization levels and cutting times on Moringa oleifera production. Cien. Inv. Agr. 46(3): 310-318. The effects of different poultry manure fertilization levels and cutting times on the growth of Moringa oleifera were evaluated. A factorial design comparing six levels of poultry manure $\left(0,50,100,150,200\right.$ and $\left.250 \mathrm{~kg} \mathrm{~N} \mathrm{ha}^{-1}\right)$ and three cutting times (4, 6 and 8 months) with four replicates was used. One month after sowing, fertilization was performed. At each cutting time, 20 plants were collected per treatment for height and diameter measurements. Stem, leaf and whole plant biomass values were assessed for each plot based on the rate of fertilization with poultry manure and the cutting time. The results showed that irrespective of the cutting time, the largest plant height and diameter were obtained with $200 \mathrm{~kg} \mathrm{~N}^{-1} \mathrm{a}^{-1}(160.37$ $\pm 6.33 \mathrm{~cm}$ and $2.37 \pm 0.33 \mathrm{~cm}$, respectively). The biomass of stems, leaves and whole plants increased with the level of $\mathrm{N}$ fertilization. The highest biomass was obtained with cutting at 6 months and a fertilization rate of $200 \mathrm{~kg} \mathrm{~N}^{-1}(1.51 \pm 0.01,0.90 \pm 0.01$ and $2.41 \pm 0.05 \mathrm{t} \mathrm{MS/}$ ha, respectively, for leaves, stems and whole plants). In conclusion, the application of poultry manure at a rate of $200 \mathrm{~kg} \mathrm{~N} \mathrm{ha}^{-1}$ at the vegetative growth stage is optimal for Moringa oleifera production.
\end{abstract}

Key words: Cutting times, fertilization, Moringa oleifera, plant biomass.

\section{Introduction}

Moringa (Moringa oleifera) is a promising food source for animals and humans in the tropics because moringa trees are fully leafed out at the

Received Jan 08, 2019. Accepted Jun 26, 2019.

Corresponding author: f.tendonkeng@univ-dschang.org; evargasb@sund.ku.dk end of the dry season when other foods are typically scarce (Aiyelaagbe, 2011). Moringa oleifera can be used as a feed supplement in cattle (Foidl et al., 2001; Fuglie, 2001a), rabbits (Nuhu, 2010) and guinea pigs (Pamo et al., 2005). This plant is an important source of protein (9-35\% of dry matter), fat (2-10\% of dry matter), fiber (9-28\% of dry matter) and starch (Makkar and Becker, 
1997; Foidl et al., 2001). It also contains minerals (0.6-11\% dry matter), alkaloids, antibiotics, vitamins $\mathrm{A}, \mathrm{B}, \mathrm{C}$ and $\mathrm{E}$ as well as cytokinin phytohormones capable of activating plant growth (Fuglie, 2001b). M. oleifera seeds have the ability to purify water, honey and milk (Benkaddour, 2016). In addition, the plant contains almost no toxins and is very drought-resistant (Foidl et al., 2001).

This plant does not grow well in clay soils and at high altitudes, such as soils in Western Cameroon. The intensification of production of this crop involves the use of chemical fertilizers (i.e., nitrates and urea) and organic fertilizers (poultry manure, rabbit manure, cattle manure) (Pamo et al., 2002; Adegun and Ayodele, 2015). However, the use of chemical fertilizers can also be a source of pollution to the environment and considerably increases the production costs of fodder. Faced with this situation, forage producers are increasingly shifting to alternative fertilizer sources that preserve the environment and improve the nutritional quality of the forage (Berkic et al., 2004), such as the use of manure and compost, which from this perspective, provide undeniable assets to different forage crops (Mboko et al., 2013). Previous studies have shown that organic fertilization (125 g plant ${ }^{-1}$ and 10 tha $^{-1}$, respectively) can improve the height and biomass of $M$. oleifera (Pamo et al., 2002; Uchena et al., 2015). However, few studies have been conducted on the use of poultry manure at different rates in $M$. oleifera production. We hypothesized that poultry manure at different rates would influence the growth of $M$. oleifera. Therefore, this study was carried out with the aim of improving the production of $M$. oleifera through adequate fertilization and the determination of the ideal cutting time.

\section{Materials and methods}

\section{Experimental site}

The study was conducted in Dschang in West Cameroon, which located at approximately 1420 $m$ in altitude $\left(5^{\circ} 26^{\prime} 77^{\prime \prime N} \mathrm{~N}, 10^{\circ} 26^{\prime} 29^{\prime \prime} \mathrm{E}\right)$. The climate is equatorial and has two seasons with a total annual rainfall of $1800-2000 \mathrm{~mm}$. The average annual temperature is $20^{\circ} \mathrm{C}$, with an annual total of 1,200 hours of sunshine. The soil of the study site had a clay soil texture with $62 \%$ sand, $10 \%$ silt and $28 \%$ clay. The soil $\mathrm{pH}$ was 4.8 , and the $\mathrm{C} / \mathrm{N}$ ratio is 22 . During the trial period (May 2017 to February 2018), rainfall data were collected daily at $0800 \mathrm{~h}$ am at the experimental site. The highest $(431.6 \mathrm{~mm})$ precipitation was reported in August 2017 (Figure 1).

An analysis of the chemical and textural composition of the soil was performed before the preparation of the soil. Samples were taken from the 0 to $20 \mathrm{~cm}$ of soil layer. The chemical analysis of the soil (Table 1) was carried out at the Laboratory

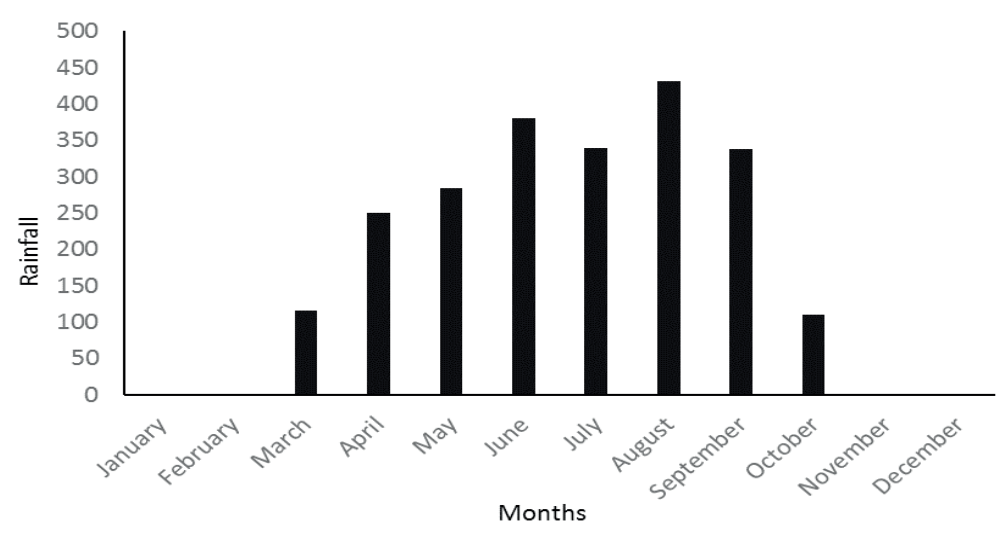

Figure 1: Rainfall (mm) in Dschang, West Cameroon 
of Soil Analysis and Environmental Chemistry (LABSAEC) of the University of Dschang following the method described by Pauwels et al. (1992).

Table 1. Physico-chemical characteristics of the soil.

\begin{tabular}{lc}
\hline Parameters & Values \\
\hline Depth & $0-20 \mathrm{~cm}$ \\
Texture (\%) & \\
Sand & 62 \\
Total silt & 10 \\
Clay & 28 \\
Textural class & $\mathrm{L}$ \\
Ground reaction & \\
Water-pH & 4.8 \\
KCL-pH & 4.0 \\
Organic matter & \\
Cobalt (\%) & 6.60 \\
Molybdenum (\%) & 11.35 \\
Total N (g kg-1) & 2.70 \\
C/N & 22 \\
Exchangeable cations (meq $100 \mathrm{~g}^{-1}$ ) & \\
Calcium & 11 \\
Magnesium & 3 \\
Potassium & 0.70 \\
Sodium & 0.08 \\
Sum of bases (SB) & 14.78 \\
Cation exchange capacity & \\
CEC at pH 7 & \\
Saturation in bases (\%) & \\
Assimilated phosphorus & 36 \\
Phosphorus Bray II & \\
\hline
\end{tabular}

Description, origin and chemical composition of the fertilizer source

The poultry manure used as a source of $\mathrm{N}$ was obtained from a commercial laying hen (birds were eight months of age) farm located in Dschang, Cameroon. The chemical composition of the poultry manure showed that it contained organic matter $\left(5.3 \mathrm{~g} \mathrm{~kg}^{-1}\right)$, nitrogen $\left(2.4 \mathrm{~g} \mathrm{~kg}^{-1}\right)$, carbon (3.1 $\left.\mathrm{g} \mathrm{kg}^{-1}\right)$, potassium (3382 ppm), sodium (617 ppm) and phosphorus (911 ppm). The plot used for the experiment was plowed manually with a hoe, and $3-\mathrm{m}^{2}$ plots spaced $0.5 \mathrm{~m}$ apart from each other were made. Then, $25 \%$ of simple superphosphate $\left(100 \mathrm{~kg} \mathrm{ha}^{-1}\right)$ was applied to all the experimental plots as the basic fertilizer. Seeds from a sweet variety of $M$. oleifera were used. On the eve of sowing, the viable (leathery) seeds were sorted and soaked in cold water. The next day, these seeds were sown at approximately $2 \mathrm{~cm}$ deep and at a density of $30 \times 30 \mathrm{~cm}$. One month after sowing, 6 levels of $\mathrm{N}(0,50,100,150,200$ and $250 \mathrm{~kg} \mathrm{~N} \mathrm{ha}^{-1}$ ) were applied in a completely randomized block design to 72 plots $(1.5 \times 2 \mathrm{~m} ; 12$ per level of $\mathrm{N}$ ). The quantities of poultry manure corresponding to the $\mathrm{N}$ levels applied are shown in Table 2. These quantities were determined by the $\mathrm{N}$ contents of the manure obtained after analysis. The experimental site was weeded and cleaned every week. A factorial design comparing six levels of poultry manure corresponding to six levels of $\mathrm{N}(0,50,100,150,200$ and $250 \mathrm{~kg} \mathrm{~N}$ $\mathrm{ha}^{-1}$ ) and three cutting times (4, 6 and 8 months) on $3-\mathrm{m}^{2}$ plots with three repetitions in each treatment was used. A total of 72 experimental plots were made.

Table 2. Quantities of poultry manure corresponding to the $\mathrm{N}$ fertilizer levels applied to Moringa oleifera

\begin{tabular}{lcc}
\hline $\begin{array}{l}\text { Fertilization level } \\
\left(\mathrm{kg} \mathrm{N} \mathrm{ha}^{-1}\right)\end{array}$ & $\begin{array}{c}\text { Total quantity of } \\
\text { applied fertilizer }(\mathrm{kg} \\
\left.\mathrm{ha}^{-1}\right)\end{array}$ & $\begin{array}{c}\text { Quantity } \\
\text { supplied }(\mathrm{kg} \mathrm{N} \\
\left.\mathrm{ha}^{-1}\right)\end{array}$ \\
\hline 1 & 0 & 0 \\
2 & 2083 & 50 \\
3 & 4166 & 100 \\
4 & 6250 & 150 \\
5 & 8333 & 200 \\
6 & 10416 & 250 \\
\hline
\end{tabular}

Experimental design, data collection and statistical analysis

At 4, 6 and 8 months after fertilization, the biomasses of the leaves, stems and whole plants of $M$. oleifera were evaluated. The height and radial growth were evaluated at the same time. Using a measuring tape, the heights of 20 plants per treatment and their regrowth were evaluated every month. On the same plants, the diameter was taken using a Vernier caliper. After harvest, 20 plants were randomly selected, and the leaves and stems were separated and weighed for determination of leaf and stem biomass. A $500 \mathrm{~g}$ sample of leaves and stems was taken and dried 
at room temperature to constant weight for the determination of dry matter (yield per t $\mathrm{DM} \mathrm{ha}^{-1}$ ).

M. oleifera production data were subjected to two-factor analysis of variance (ANOVA) (poultry manure levels and cutting times) following the General Linear Model (GLM) with SPSS 20.0 statistical software. When there were significant differences between treatments, Duncan's test was used to separate the means. Statistical significance was declared at $(P<0.05)$.

\section{Results}

\section{Growth height of Moringa oleifera}

Four months after sowing, the plant heights of the plots fertilized with 200 and $250 \mathrm{~kg} \mathrm{~N} \mathrm{ha}^{-1}$ of manure were comparable $(P>0.05)$ but significantly higher $(P<0.05)$ than those of the plots fertilized with $150,100,50$ and $0 \mathrm{~kg} \mathrm{~N}^{-1}$, respectively (Table 3). During this period, the plant heights of the plots fertilized with 150, 100, 50 and $0 \mathrm{~kg} \mathrm{~N} \mathrm{ha}^{-1}$ were comparable $(P>0.05)$. At 6 and 8 months, the plant height of the plots fertilized with 200 and $250 \mathrm{~kg} \mathrm{~N} \mathrm{ha}^{-1}$ of manure were comparable $(P$ $>0.05)$ but significantly higher $(P<0.05)$ than those of other fertilization levels. Regardless of the fertilization levels, the plant heights obtained at 8 months were significantly higher $(P<0.05)$ than those obtained at 4 and 6 months.

Four months after sowing, the plant diameters of the plots fertilized with 200 and $250 \mathrm{~kg} \mathrm{~N}$ ha $^{-1}$ of manure were comparable $(P>0.05)$ but significantly higher $(P<0.05)$ than those of the plots fertilized with $150,100,50$ and $0 \mathrm{~kg} \mathrm{~N} \mathrm{ha}^{-1}$, respectively (Table 3). The same result was observed at 6 months. At 8 months, the diameters of the plants fertilized with $150,100,50$ and $0 \mathrm{~kg} \mathrm{~N}$ ha $^{-1}$ were comparable $(P>0.05)$ but significantly lower $(P<0.05)$ than those fertilized with 200 and $250 \mathrm{~kg} \mathrm{~N} \mathrm{ha}^{-1}$, which were comparable $(P>$ $0.05)$. Regardless of the fertilization levels, the plant diameters obtained at 8 months were sig- nificantly higher $(P<0.05)$ than those obtained at 4 and 6 months.

Total biomass, leaf biomass, stem biomass and stem/leaf ratio of Moringa oleifera

The increase in the whole plant biomass based on poultry manure fertilization levels is presented in Table 3. Biomass increased with $\mathrm{N}$ level. The highest $(P<0.05)$ yield was obtained with 200 $\mathrm{kg} \mathrm{N} \mathrm{ha}^{-1}$ at all cutting times except at 4 months, where $250 \mathrm{~kg} \mathrm{~N}^{-1}$ gave the highest biomass (0.37 t DM ha' $\left.{ }^{-1}\right)$.

Regardless of the cutting time, the biomass of fertilized plants was significantly $(P<0.05)$ higher than that of unfertilized plants. At four months, the biomass obtained from plants fertilized with $100,150,200$ and $250 \mathrm{~kg} \mathrm{~N}^{-1}$ was comparable $(P>0.05)(0.32,0.31,0.35$ and 0.37 t DM ha ${ }^{-1}$, respectively). The same observation was made for the biomass obtained from plants fertilized with 50,100 and $150 \mathrm{~kg} \mathrm{~N}^{-1}$. At six months of age, the highest total biomass $(2.41 \mathrm{t}$ $\mathrm{DM} \mathrm{ha}^{-1}$ ) was obtained from plants fertilized at $200 \mathrm{~kg} \mathrm{~N} \mathrm{ha}^{-1}$. The second highest biomass was obtained with plants fertilized at $250 \mathrm{~kg} \mathrm{~N} \mathrm{ha}^{-1}$. The biomass obtained from plants fertilized with 50,100 and $150 \mathrm{~kg} \mathrm{~N} \mathrm{ha}^{-1}$ was comparable $(P>$ 0.05). At eight months, the total biomass (1.75 t $\left.\mathrm{DM} \mathrm{ha}^{-1}\right)$ of plants fertilized at $200 \mathrm{~kg} \mathrm{~N} \mathrm{ha}^{-1}$ was significantly $(P<0.05)$ higher than that of plants fertilized at rates of 250,150, 100 and $50 \mathrm{~kg} \mathrm{~N}$ $\mathrm{ha}^{-1}$, which showed comparable values. The total biomass of plants fertilized with $250 \mathrm{~kg} \mathrm{~N} \mathrm{ha}{ }^{-1}$ was reduced by $46.1 \%$ compared to that of plants fertilized at $200 \mathrm{~kg} \mathrm{~N} \mathrm{ha}^{-1}$.

The biomasses obtained at 6 and 8 months were comparable $(P>0.05)$ when plants were fertilized at 50,100 and $150 \mathrm{~kg} \mathrm{~N} \mathrm{ha}^{-1}$. These biomasses were significantly $(P<0.05)$ higher than those obtained at 4 months. In unfertilized plots, the biomasses obtained at 6 months were significantly $(P<0.05)$ higher than those obtained at 4 and 8 
Table 3. Effect of poultry manure fertilization levels on total biomass, leaf biomass, stem biomass and stem/leaf ratio production ( $\mathrm{t} \mathrm{DM} \mathrm{ha}^{-1}$ ) of $M$. oleifera with different cutting times.

\begin{tabular}{|c|c|c|c|c|c|c|c|c|}
\hline \multirow{2}{*}{$\begin{array}{l}\text { Cutting times } \\
\text { (months) }\end{array}$} & \multicolumn{7}{|c|}{ Plant height $(\mathrm{cm})$} & \multirow[b]{2}{*}{$P$ - value } \\
\hline & 0 & 50 & 100 & 150 & 200 & 250 & SEM & \\
\hline 4 & $29.67^{\mathrm{aA}}$ & $30.29^{\mathrm{aA}}$ & $31.06^{\mathrm{aA}}$ & $31.78^{\mathrm{aA}}$ & $37.22^{\mathrm{bA}}$ & $37.02^{\mathrm{bA}}$ & 0.441 & $<0.05$ \\
\hline 6 & $43.63^{\mathrm{aB}}$ & $55.23^{\mathrm{bB}}$ & $65.54^{\mathrm{cB}}$ & $54.87^{\mathrm{bA}}$ & $78.43^{\mathrm{dB}}$ & $79.03^{\mathrm{dB}}$ & 1.393 & $<0.05$ \\
\hline 8 & $128.35^{\mathrm{aC}}$ & $141.47^{\mathrm{bC}}$ & $146.65^{\mathrm{bcc}}$ & $133.59^{\mathrm{bB}}$ & $160.38^{\mathrm{cC}}$ & $155.47^{\mathrm{cC}}$ & 2.414 & $<0.05$ \\
\hline SEM & 15.76 & 17.20 & 17.41 & 15.78 & 18.97 & 17.61 & & \\
\hline$P$ - value & $<0.05$ & $<0.05$ & $<0.05$ & $<0.05$ & $<0.05$ & $<0.05$ & & \\
\hline \multicolumn{9}{|c|}{ Plant diameter $(\mathrm{cm})$} \\
\hline 4 & $0.58^{\mathrm{aA}}$ & $0.65^{\mathrm{bA}}$ & $0.70^{\mathrm{bA}}$ & $0.66^{\mathrm{bA}}$ & $0.79^{\mathrm{cA}}$ & $0.79^{\mathrm{cA}}$ & 0.008 & $<0.05$ \\
\hline 6 & $0.92^{\mathrm{aA}}$ & $0.89^{\mathrm{aB}}$ & $1.26^{\mathrm{bB}}$ & $1.19^{\text {вв }}$ & $1.38^{\mathrm{cB}}$ & $1.47^{\mathrm{cB}}$ & 0.018 & $<0.05$ \\
\hline 8 & $1.88^{\mathrm{aB}}$ & $1.91^{\mathrm{aB}}$ & $1.93^{\mathrm{aC}}$ & $1.96^{\mathrm{aC}}$ & $2.30^{\mathrm{bC}}$ & $2.05^{\mathrm{bC}}$ & 0.018 & $<0.05$ \\
\hline SEM & 0.228 & 0.193 & 0.178 & 0.189 & 0.221 & 0.183 & & \\
\hline$P$ - value & $<0.05$ & $<0.05$ & $<0.05$ & $<0.05$ & $<0.05$ & $<0.05$ & & \\
\hline \multicolumn{9}{|c|}{ Total biomass (t DM ha-1) } \\
\hline 4 & $0.20^{\mathrm{cC}}$ & $0.26^{\mathrm{bB}}$ & $0.32^{\mathrm{abB}}$ & $0.31^{\mathrm{abB}}$ & $0.35^{\mathrm{aC}}$ & $0.37^{\mathrm{aC}}$ & 0.020 & $<0.05$ \\
\hline 6 & $0.41^{\mathrm{dA}}$ & $0.67^{\mathrm{cA}}$ & $0.75^{\mathrm{cA}}$ & $0.74^{\mathrm{cA}}$ & $2.41^{\mathrm{aA}}$ & $1.11^{\mathrm{bA}}$ & 0.030 & $<0.05$ \\
\hline 8 & $0.30^{\mathrm{cB}}$ & $0.69^{\mathrm{bA}}$ & $0.74^{\mathrm{bA}}$ & $0.73^{\mathrm{bA}}$ & $1.75^{\mathrm{aB}}$ & $0.72^{\mathrm{bB}}$ & 0.040 & $<0.05$ \\
\hline SEM & 0.030 & 0.060 & 0.010 & 0.050 & 0.070 & 0.050 & & \\
\hline$P$ - value & $<0.05$ & $<0.05$ & $<0.05$ & $<0.05$ & $<0.05$ & $<0.05$ & & \\
\hline \multicolumn{9}{|c|}{ Leaf biomass (t DM ha-1) } \\
\hline 4 & $0.13^{\mathrm{cC}}$ & $0.17^{\mathrm{bcB}}$ & $0.22^{\mathrm{abB}}$ & $0.22^{\mathrm{abB}}$ & $0.22^{\mathrm{abC}}$ & $0.25^{\mathrm{aC}}$ & 0.01 & $<0.05$ \\
\hline 6 & $0.27^{\mathrm{dA}}$ & $0.46^{\mathrm{cA}}$ & $0.51^{\mathrm{cA}}$ & $0.51^{\mathrm{cA}}$ & $1.51^{\mathrm{aA}}$ & $0.79^{\mathrm{bA}}$ & 0.05 & $<0.05$ \\
\hline 8 & $0.19^{\mathrm{cB}}$ & $0.38^{\mathrm{bA}}$ & $0.44^{\mathrm{bA}}$ & $0.48^{\mathrm{bA}}$ & $1.21^{\mathrm{aB}}$ & $0.49^{\text {bв }}$ & 0.05 & $<0.05$ \\
\hline SEM & 0.02 & 0.04 & 0.03 & 0.05 & 0.10 & 0.08 & & \\
\hline$P$ - value & 0.05 & $<0.05$ & $<0.05$ & $<0.05$ & $<0.05$ & $<0.05$ & & \\
\hline \multicolumn{9}{|c|}{ Stem biomass (t DM ha $\left.{ }^{-1}\right)$} \\
\hline 4 & $0.07^{\mathrm{cC}}$ & $0.09^{\mathrm{bcc}}$ & $0.10^{\mathrm{bB}}$ & $0.10^{\mathrm{bB}}$ & $0.13^{\mathrm{aC}}$ & $0.12^{\mathrm{aC}}$ & 0.02 & $<0.05$ \\
\hline 6 & $0.13^{\mathrm{cA}}$ & $0.21^{\mathrm{bcB}}$ & $0.25^{\mathrm{bcA}}$ & $0.26^{\mathrm{bcA}}$ & $0.90^{\mathrm{aA}}$ & $0.31^{\mathrm{bA}}$ & 0.04 & $<0.05$ \\
\hline 8 & $0.10^{\mathrm{cB}}$ & $0.30^{\mathrm{bA}}$ & $0.30^{\mathrm{bA}}$ & $0.25^{\mathrm{bcA}}$ & $0.54^{\mathrm{aB}}$ & $0.23^{\mathrm{bcB}}$ & 0.04 & $<0.05$ \\
\hline SEM & 0.02 & 0.04 & 0.03 & 0.03 & 0.16 & 0.03 & & \\
\hline$P$ - value & $<0.05$ & $<0.05$ & $<0.05$ & $<0.05$ & $<0.05$ & $<0.05$ & & \\
\hline \multicolumn{9}{|c|}{ Stem/leaf ratio } \\
\hline 4 & $0.53^{\mathrm{abB}}$ & $0.51^{\mathrm{abB}}$ & $0.46^{\mathrm{bB}}$ & $0.48^{\mathrm{bB}}$ & $0.61^{\mathrm{aB}}$ & $0.51^{\mathrm{abB}}$ & 0.02 & $<0.05$ \\
\hline 6 & $0.49^{\mathrm{abB}}$ & $0.46^{\mathrm{abB}}$ & $0.48^{\mathrm{abB}}$ & $0.51^{\mathrm{abB}}$ & $0.61^{\mathrm{aB}}$ & $0.41^{\mathrm{bB}}$ & 0.02 & $<0.05$ \\
\hline 8 & $0.92^{\mathrm{abA}}$ & $0.92^{\mathrm{abA}}$ & $1.05^{\mathrm{abA}}$ & $1.15^{\mathrm{aA}}$ & $0.99^{\mathrm{abA}}$ & $0.83^{\mathrm{bA}}$ & 0.04 & $<0.05$ \\
\hline SEM & 0.06 & 0.07 & 0.08 & 0.10 & 0.07 & 0.07 & & \\
\hline$P$ - value & $<0.05$ & $<0.05$ & $<0.05$ & $<0.05$ & $<0.05$ & $<0.05$ & & \\
\hline
\end{tabular}

a, b, c, d: In the same column, the assigned values of the same letter do not differ significantly ( $\mathrm{P}>0.05)$; SEM: Standard Error of Mean; P: Probability. A, B and C: In the same row, the assigned values of the same letter do not differ significantly $(\mathrm{P}>0.05) .0=$ without manure; $50=50 \mathrm{~kg} \mathrm{~N}^{-1}$ manure; $100=100 \mathrm{~kg} \mathrm{~N}^{-1}$ manure; $150=150 \mathrm{~kg} \mathrm{~N}^{-1}$ manure; $200=200 \mathrm{~kg} \mathrm{~N}^{-1} \mathrm{a}^{-1}$ manure and $250=250 \mathrm{~kg} \mathrm{~N}^{-1}$ manure. 
months. The same effect was observed with plants fertilized at 200 and $250 \mathrm{~kg} \mathrm{~N} \mathrm{ha}^{-1}$.

Table 3 shows the $M$. oleifera leaf biomass values. Leaf biomass increased with the fertilization level to reach the highest levels in plants fertilized at $200 \mathrm{~kg} \mathrm{~N} \mathrm{ha}^{-1}$ at all cutting times. Regardless of the cutting times, the leaf biomass of the fertilized plots was significantly $(P<0.05)$ higher than that of the unfertilized plots. The leaf biomass obtained with 100, 150, 200 and $250 \mathrm{~kg} \mathrm{~N}^{-1}$ was comparable $(P>0.05)(0.22,0.22,0.22$ and $0.25 \mathrm{t}$ $\mathrm{DM} \mathrm{ha}^{-1}$, respectively) at four months. The same observation was made for the biomass obtained with 50,100 and $150 \mathrm{~kg} \mathrm{~N} \mathrm{ha}^{-1}$. At six months of age, the leaf biomass was significantly $(P<0.05)$ highest (1.51 $\left.\mathrm{t} \mathrm{DM} \mathrm{ha}^{-1}\right)$ in plants fertilized at 200 $\mathrm{kg} \mathrm{N} \mathrm{ha}^{-1}$ and lowest $\left(0.27 \mathrm{t} \mathrm{DM} \mathrm{ha}^{-1}\right)$ in unfertilized plants. The biomass obtained with 50, 100 and $150 \mathrm{~kg} \mathrm{~N} \mathrm{ha}^{-1}$ was comparable $(P>0.05)$. At eight months, the leaf biomass (1.21 t DM ha- $\left.{ }^{-1}\right)$ achieved with $200 \mathrm{~kg} \mathrm{~N}^{-1}$ was significantly $(P<$ $0.05)$ higher than those values obtained with 250 , 150,100 and $50 \mathrm{~kg} \mathrm{~N} \mathrm{ha}^{-1}$, respectively, which were comparable among each other. The leaf biomass (at 6 and 8 months) of the plants fertilized with $250 \mathrm{~kg} \mathrm{~N} \mathrm{ha}^{-1}$ was reduced by $52.3 \%$ compared to that of plants fertilized with $200 \mathrm{~kg} \mathrm{~N} \mathrm{ha}^{-1}$.

According to the cutting times, leaf biomasses obtained at 6 and 8 months were comparable $(P>0.05)$ when plants were fertilized at 50,100 and $150 \mathrm{~kg} \mathrm{~N} \mathrm{ha}^{-1}$. These biomasses were significantly $(P<0.05)$ higher than those obtained at 4 months. In unfertilized plots, leaf biomasses obtained at 6 months were significantly $(P<0.05)$ higher than those obtained at 4 and 8 months. The same effect was observed with plants fertilized at 200 and $250 \mathrm{~kg} \mathrm{~N} \mathrm{ha}^{-1}$.

The stem biomass of $M$. oleifera increased with the level of fertilization to reach the maximum yield with plants fertilized at the level of $200 \mathrm{~kg}$ $\mathrm{N} \mathrm{ha}^{-1}$ at all cutting times (Table 3). Regardless of the cutting time, the stem biomass of fertilized plants was significantly $(P<0.05)$ higher than that of unfertilized plants. At four months, stem biomasses obtained from plots fertilized with 200 and $250 \mathrm{~kg} \mathrm{~N}^{-1}$ were comparable $(P$ $>0.05)$ (0.13 and 0.12 t DM ha $^{-1}$, respectively) but significantly $(P<0.05)$ higher than those of plants fertilized at $0,50,100$ and $150 \mathrm{~kg} \mathrm{~N} \mathrm{ha}^{-1}$. The biomass of the stems obtained from plants fertilized with 50,100 and $150 \mathrm{~kg} \mathrm{~N}^{-1}$ was comparable $(P>0.05)$. The same observation was made for stems of plants fertilized at 0 and $50 \mathrm{~kg} \mathrm{~N} \mathrm{ha}^{-1}$. At six months, the highest stem biomass $\left(0.90 \mathrm{t} \mathrm{DM} \mathrm{ha}^{-1}\right)$ was obtained with plants fertilized at $200 \mathrm{~kg} \mathrm{~N} \mathrm{ha}^{-1}$. This biomass was followed by those of plants fertilized at 250, 150, 100 and $50 \mathrm{~kg} \mathrm{~N} \mathrm{ha}^{-1}$, which were comparable $(P$ $>0.05)$. At eight months, the stem biomass (1.21 $\left.\pm 0.13 \mathrm{DM} \mathrm{ha}^{-1}\right)$ in the plot fertilized at $200 \mathrm{~kg}$ $\mathrm{N} \mathrm{ha}^{-1}$ was significantly $(P<0.05)$ higher than those of plants fertilized at 250, 150, 100 and 50 $\mathrm{kg} \mathrm{N} \mathrm{ha}^{-1}$, respectively, which were comparable among each other. The biomass of the stems on the plot fertilized at $250 \mathrm{~kg} \mathrm{~N} \mathrm{ha}^{-1}$ decreased by approximately $34.44 \%$ compared to that of the plants fertilized at $200 \mathrm{~kg} \mathrm{~N} \mathrm{ha}^{-1}$.

Stem biomasses obtained at 6 and 8 months were comparable $(P>0.05)$ when plants were fertilized at 50, 100 and $150 \mathrm{~kg} \mathrm{~N}^{-1}$ (Table 3). These biomasses were significantly $(P<0.05)$ higher than those obtained at 4 months. In unfertilized plots, the stem biomasses obtained at 6 months were significantly $(P<0.05)$ higher than those obtained at 4 and 8 months. The same trend was observed with plants fertilized at 200 and 250 $\mathrm{kg} \mathrm{N} \mathrm{ha-1}$.

The stem/leaf ratio was significantly $(P<0.05)$ influenced by cutting time and fertilization level (Table 3). The stem/leaf ratio obtained at 8 months was significantly $(P<0.05)$ higher than those obtained at 4 and 6 months, which were comparable $(P>0.05)$. At four months, the stem/ leaf ratio ranged from 0.46 to 0.61 . At six months, the ratio of stems/leaves varied from 0.41 to 0.61 , whereas at eight months, it ranged from 0.83 to 1.15. The ratio of stems/leaves obtained at eight 
months was significantly $(P<0.05)$ higher than that obtained at four and six months. On the other hand, the stem/leaf ratios obtained at four and six months were comparable $(P>0.05)$.

\section{Discussion}

At four months after sowing, fertilization at 200 and $250 \mathrm{~kg} \mathrm{~N}^{-1}$ resulted in a higher rate of increase in height and diameter than other fertilization rates. This could indicate the beginning of the stimulation of organic matter development in the plant (Pamo et al., 2002). This maximum stimulation of biometric growth realized with the application of poultry manure continued until 8 months after sowing. The fertilization rates of 200 and $250 \mathrm{~kg} \mathrm{~N} \mathrm{ha}^{-1}$ explained the multiple effects due to the application of manure on a clay soil. Indeed, manure has a porous and spongy structure (Pamo et al., 2002). Manure increases the aeration and $\mathrm{O}_{2}$ content of clay soils (Pamo et al., 2002). The decomposition of organic fertilizer enriches the soil with humus consisting mainly of cellulose, hemicelluloses and lignin, which are a source of energy for soil microorganisms (Keeton et al., 1993). In addition, high application rates of manure may inhibit Fe and Mn toxicity (because the excess of these ions is fixed by the ammonium ions; Palm et al., 2001). The results obtained were consistent with those obtained by Foidl et al. (2001) and Anamayi et al. (2016), who showed that cow manure improved the growth of M. oleifera in Nicaragua and Nigeria, respectively. Similarly, Artin and Rice (2002) showed that on very poor and alkaline soil in Haiti, compost fertilization (organic manure) improved the growth of M. oleifera.

In this study, fertilization positively influenced the biomass production of $M$. oleifera plants and their various parts. This observation agrees with those of Uchenna et al. (2015), who showed that M. oleifera plants fertilized with 5 and $10 \mathrm{~kg} \mathrm{~N}$ $\mathrm{ha}^{-1}$ of poultry manure had higher biomasses than unfertilized plants. In fact, fertilization increases the speed of vegetative growth, thus increasing production for a given growth stage or reducing the time required to reach a defined yield (Tendonkeng et al., 2011).

In the present study, the biomass of the whole plants, leaves and stems increased with the level of fertilization up to a threshold beyond which it began to decrease. The yield reduction observed following this fertilization threshold agrees with observations by Limani and De Vienne (2001), Tendonkeng et al. (2011), who showed that $\mathrm{N}$ intake at a rate higher than the potential growth needs of the plant do not increase the forage yield because the $\mathrm{N}$ becomes toxic to the plant. This maximum level of fertilization was found to be $200 \mathrm{~kg} \mathrm{~N} \mathrm{ha}^{-1}$ in our study. In addition, Maurice et al. (1985) had previously reported that $\mathrm{N}$ fertilization at rates greater than the potential growth needs of the plant leads to a decrease in biomass production due to ammonium ion toxicity. Similarly, Lawlor et al. (2001) noted that when $\mathrm{N}$ intake exceeds the plant's needs, the nitrogen use efficiency of the plant decreases because the $\mathrm{N}$ has become saturated.

The ratio of stems/leaves obtained at eight months was higher than that obtained at four and six months, and this could be explained by the fact that this cutting period took place in the middle of the dry season (January) and despite the fact that the plants were watered, the latter lost their leaves in favor of stem development. The stem/leaf ratio thus indicates the best period for obtaining leaves or stems for the production of M. oleifera. In production, the leaves should be harvested 4 and 6 months after sowing, while the stems should be harvested 8 months after sowing and preferably in the dry season.

The main conclusions are as follows. Overall, the application of 200 and $250 \mathrm{~kg} \mathrm{~N} \mathrm{ha}^{-1}$ of poultry manure to $M$. oleifera generated the greatest height and stem collar diameter among all levels of fertilization. Similarly, the application of $200 \mathrm{~kg} \mathrm{~N} \mathrm{ha}^{-1}$ improved the biomass 
of whole plants, leaves and stems compared to other levels of fertilization. Based on the study findings, it is suggested that $M$. oleifera be fertilized with $200 \mathrm{~kg} \mathrm{~N} \mathrm{ha}^{-1}$ and harvested between 4 and 6 months to achieve the best biomass and stem/leaf ratio.

\title{
Resumen
}

\begin{abstract}
M. Mouchili, F. Tendonkeng, E. Miégoué, D. Fokom Wauffo, H. Mekuiko Watsop, P.E. Tedonkeng, y E. Vargas-Bello-Pérez. 2019. Efectos de diferentes niveles de fertilización con guano de aves y tiempos de corte en la producción de Moringa oleifera. Cien. Inv. Agr. 46(3): 310-318. El efecto de diferentes niveles de fertilización con guano de ave y tiempos de corte fueron evaluados sobre el crecimiento de Moringa oleífera. En un diseño factorial con seis niveles con fertilización de guano de ave $\left(0,50,100,150,200\right.$ y $\left.250 \mathrm{~kg} \mathrm{~N}^{-1}\right)$ y tres tiempos de corte (4, 6 y 8 meses) con cuatro replicas fue utilizado. Después de un mes de siembra, se llevó a cabo la fertilización. En cada tiempo de corte, 20 plantas fueron colectadas por tratamiento para las mediciones de altura y diámetro. La biomasa del tallo, hoja y planta entera de Moringa oleífera fue analizada por cada parcela dependiendo de su nivel de fertilización con guano de ave y su respectivo tiempo de corte. Los resultados mostraron que independiente del tiempo de corte, la mayor altura y diámetro de la planta fue obtenida con $200 \mathrm{~kg} \mathrm{~N} \mathrm{ha}^{-1}$. La biomasa del tallo, hoja y planta entera aumentó conforme el nivel de fertilización aumentó. La mejor biomasa se obtuvo en el corte a los 6 meses $\left(1.51,0.90\right.$ y $2.41 \mathrm{t} \mathrm{MS} \mathrm{ha}^{-1}$ respectivamente para hojas, tallo y planta entera. En conclusión, la utilización de guano de ave a razón de $200 \mathrm{~kg} \mathrm{~N}$ ha $^{-1}$ es la más adecuada para el crecimiento de Moringa oleífera en estado vegetativo.
\end{abstract}

Palabras clave: Biomasa, fertilización, Moringa oleifera, tiempos de corte.

\section{References}

Adegun, M.K., O.J. Ayodele. 2015. Growth and yield of Moringa oleifera 'as influenced by spacing and organic manures in South-Western Nigeria. Int J Agron Agric Res. 6:30-37.

Aiyelaagbe, I.O.O. 2011. Nigerian Horticulture: Facing the challenges of human health and agricultural productivity. Keynote address presented at the 29th Annual National Conference of Horticultural Society of Nigeria 24-29. Makurdi.

Anamayi, S.E., O.N. Oladele, R.A. Suleiman, E.O. Oloyede, U. Yahaya. 2016. Effect of cow dung and N.P.K fertilizer at different levels on the growth performance and nutrient composition of Moringa oleifera. Anim Exp Biol. 4:35-39.
Artin, M., L.P. Rice. 2002. The Moringa tree. An Echo Technical Note. Echo staff. 13:1-19.

Benkaddour, N. 2016. Contribution à l'etude de l'efficacite de la graine de Moringa oleifera dans la depollution des eaux d'oued safsaf. Mémoire de fin d'étude pour l'obtention du diplome d'ingenieur d'etat en agroforesterie option: Technologie Des Industries Agro-Alimentaires.

Berkić, S., Z. Milakovic, A. Kristek, M. Antunovié. 2004. Pea yield and its quality depending on inoculation, nitrogen and molybdenum fertilization. Plant, Soil Env. 39(1):39-45.

Foidl, N., H.P.S. Makkar, K. Berker. 2001. The potential of Moringa oleifera for agricultural and industrial uses. In: Fuglie, L. J. (ed.). The miracle 
tree: the multiple attributes of Moringa. CTA / CWS. Dakar, Sngal. pp. 45-76.

Fuglie, L.J. 2001a. Introduction to the multiple uses of Moringa. In: Fuglie, L. J. (ed.). The miracle tree: the multiple attributes of Moringa. CTA / CWS. Dakar, Sénégal. pp. 7-10.

Fuglie, L.J. 2001b. Natural nutrition for the tropics. In: Fuglie, L. J. (ed.). The miracle tree: the multiple attributes of Moringa. CTA / CWS. Dakar, Sénégal. pp 103-115.

Keeton, W.T., J.L. Gould, C.G. Gould. 1993. Biological sciences. Norton and Company Inc. New York/London. pp 742-839.

Limani, A., D. De Vienne. 2001. Natural genetic variability in nitrogen Metabolism. In: Plant Nitrogen, Lea PJ, Morot, Gaudry JF (eds), INRA; 369-378.

Lawlor, D.W., G. Lemaire, G. François. 2001. Nitrogen, plant growth and crop yield. In: Lea P.J. and Morot-Gaudry J.F. (eds). Plant Nitrogen. 2001. INRA. Pp 343-367.

Makkar, H.P.S., and K. Becker. 1997. Nutrients and anti- quality factors in different morphological parts of the Moringa oleifera tree. J. Agric. Sci. 128:311-32.

Maurice, E.H., F.B. Robert, S.M. Darrel. 1985. Forages: The science of grass and agriculture. Iowa State University press. Arnes, Iowa, USA. Pp. 318-325.

Mboko, A.V., F. Tendonkeng, F.N.E. Matumuni, G.T. Zougou, E. Miégoué, B. Boukila, T.E. Pamo. 2013. Effet comparé de deux légumineuses fertilisées au molybdène sur la croissance et le rendement de Brachiaria ruziziensis à différentes périodes de fauche dans l'ouest Cameroun. Int. Form. Group 7:2513-2525.

Nuhu, F. 2010. Effect of moringa leaf meal (molm) on nutrient digestibility, growth, carcass and blood indices of weaner rabbits. A thesis submitted to the school of graduate studies, kwame nk- rumah university of science and technology, kumasi, in partial fulfilment of the requirements for the award of master of science degree in animal nutrition. P84.

Palm, C.A., C.N. Gachengo, R.J. Delve, G. Cadisch, K.E. Giller. 2001. Organic input for soil fertility management in tropical agroecosystems: Application of organic resource database. Agriculture, Ecosystems and Environment, 83:27-42.

Pamo, T.E., T.A. Niba, A.F. Fonteh, F. Tendonkeng, J.R. Kana, B. Boukila, J. Tsachoung. 2005. Effet de la supplémentation au Moringa oleifera ou aux blocs multinutritionnels sur l'évolution du poids post partum et la croissance pré-sevrage des cobayes (Cavia porcellus L.). Livestock Res Rural Dev. p17.

Pamo, T. E., B. Boukila, F. Tendonkeng, J.R. Kana, B.L. Tonfack, M.C.S Momo. 2002. Influence de la fumure organique, du NPK et du mélange des deux fertilisants sur la croissance de Moringa oleifera Lam. dans l'Ouest Cameroun.

Pauwels, J.M., E. Van Ranst, M.G. Verloo, Z.A. Mvondo. 1992. Manuel de laboratoire de pédologie. A.G. Building, Place du Champ de mars 5, Boîte 57, Bruxelles 1050. Publications Agricoles 28, pp. 191-208.

Tendonkeng, F., B. Boukila, T.E. Pamo, A.V. Mboko, N.E.F. Matumuini. 2011. Effets direct et résiduel de différents niveaux de fertilisation azotée sur la croissance et le rendement de Brachiaria ruziziensis à différents stades phénologiques. Tropicultura 29:197-204.

Uchenna, M.N., E.E. Amos, P.B. Kayode, I.P. Ezeaku. 2015. Application of poultry manure and the effect on growth and performance of potted Moringa (Moringa oleifera Lam) plants raised for urban dwellers use. Am J Plant Nutr Fer Tech. 5:33-39. 